\title{
Teknik Desinfeksi Perendaman dan Penyemprotan Ekstrak Mengkudu (Morinda Citrifolia Liin), terhadap Perubahan Stabilitas Dimensi Cetakan Alginat
}

\author{
Kadek Ayu Wirayuni*, Desak Nyoman Ayu Juniawati, \\ Bagian Prostodonsia, Fakultas Kedokteran Gigi, Universitas Mahasaraswati Denpasar \\ e-mail : wirayuni.dentist@gmail.com
}

\begin{abstract}
Dental material that is often used in dentistry is alginate. Alginate molding material has imbibition properties that absorb water when it comes into contact with water so that the shape is easier to expand and syneresis is the loss of water content through evaporation, causing shrinkage of the alginate mold when left too long in the open air. It is recommended that the printed product be disinfected first to avoid cross infection. One of the herbs that has antibacterial properties is mengkudu (Morinda Citrifolia Liin). The purpose of this study was to determine differences in immersion and spraying techniques with $0.5 \%$ sodium hypochlorite and noni extract 50\%, 25\% and 12\% for 5 minutes. Data were analyzed by ANOVA test. The conclusion of this study is that there is a change in the stability of the dimensions of the alginate mold in the $A B$ (anteroposterior) and BC distance inter junction techniques, at concentrations of $12 \%$ and $25 \%$, experiencing a higher increase compared to the concentration of $50 \%$ but still within the clinical tolerance limit ie below $0.5 \%$. The spraying technique has a smaller percentage change compared to the immersion technique. There is a change in dimensional stability of alginate molds with a significant difference in the immersion and spraying technique, soaking causes an increase indimensional changes compared to the spraying technique.
\end{abstract}

Keywords: Alginate, Dimensional Stability, Noni Extract

\section{Pendahuluan}

Pencetakan merupakan kegiatan yang sering dilakukan dalam bidang kedokteran gigi. Alginat merupakan bahan yang banyak digunakan sebab pencampurannya mudah dan relatif lebih murah dibanding dengan bahan cetak elastomer. Faktor yang harus diperhatikan adalah kontaminasi dengan mikroorganisme dari air liur dan darah pasien yang dapat mengakibatkan kontaminasi silang terhadap dokter gigi maupun petugas laboratorium, ditemukan $67 \%$ dari bahan-bahan yang di kirim dari dokter gigi ke laboratorium terkontaminasi oleh bakteri patogen, sehingga penting dilakukan kontrol dari penularan infeksi silang yang berasal dari mikroorganisme patogen yang menyebar melalui bahan cetak. ${ }^{1}$ Mencuci hasil cetakan alginat dengan air hanya menurukan jumlah mikroba sampai $48 \%,{ }^{2}$ sedangkan perlu dilakukan desinfeksi untuk menghindari terjadinya kontaminasi bakteri atau infeksi silang. ${ }^{3}$ Teknik desinfeksi yang digunakan dalam melakukan tindakan pencegahan terhadap infeksi silang pada hasil cetakan alginat adalah melalui tindakan perendaman dan penyemprotan, tetapi permasalahan yang ditimbulkan setelah desinfeksi adalah perubahan stabilitas dimensi dari bahan cetak. Bahan cetak alginat pada dasarnya memiliki sifat sineresis dan imbibisi karena bahan ini berupa gel. Sineresis adalah hilangnya kandungan air melalui penguapan sehingga menyebabkan pengerutan pada cetakan alginat saat dibiarkan terlalu lama pada udara terbuka. Kelembapan 
hasil cetakan alginat harus dijaga agar stabilitasnya tidak berubah, sebaliknya jika cetakan ditempatkan di dalam air, maka cetakan tersebut akan menyerap air melalui proses yang disebut imbibisi, hal ini dapat menyebabkan perubahan bentuk atau dimensi hasil cetakan sehingga mudah terjadi ekspansi yang dapat menyebabkan ketidakakuratan cetakan alginat. ${ }^{4}$ Pertimbangan yang harus diperhatikan dalam menentukan teknik dan larutan desinfektan terhadap pengaruhnya pada cetakan alginat, diantaranya berpengaruh terhadap stabilitas dimensi, detail permukaan cetakan alginat dan efek mematikan pada bakteri ${ }^{4}$ sedangkan pada penelitian yang dilakukan di Hong Kong menunjukan bahwa natrium hipoklorit merupakan larutan desinfektan bahan cetak yang paling banyak digunakan dokter gigi swasta (73\%), diikuti oleh 3 glutaraldehid (15\%), alkohol (8\%), hidrogen peroksida (4\%) dan selebihnya menggunakan produk bermerek $(8 \%) .{ }^{6}$ Penelitian yang menyatakan kekurangan sodium hipoklorit yaitu mempunyai bau yang kurang nyaman dan terasa panas jika terkena kulit, oleh karena itu mulai digunakan bahan alami sebagai bahan desinfektan. ${ }^{7}$ Mengkudu (Morinda Citrifolia Liin) merupakan salah satu desinfektan alami yang dapat dipergunakan sebagai bahan desinfeksi pada hasil cetakan. ${ }^{8}$ Mengkudu (Morinda Citrifolia Liin) dikenal sebagai anti bakteri, anti virus dan anti jamur. Daya anti bakteri dari ekstrak buah mengkudu( Morinda Citrifolia Liin) terjadi karena mengkudu mengandung zat anti bakteri yaitu senyawa flavonoid, alizarin, acubin, saponin dan minyak atrisi. ${ }^{9}$ Buah mengkudu (Morinda Cittrifolia Liin) dapat menghambat pertumbuhan Staphylococcus aureus pada konsentrasi 50\% , ${ }^{10}$ sedangkan pada penelitian konsentrasi $50 \%$ ekstrak mengkudu (Morinda Citrifolia Liin) efektif digunakan sebagai alternatif obat kumur dan menghambat pertumbuhan Streptokokus $S p$ sebagai penyebab plak gigi. ${ }^{11}$ Konsentrasi $25 \%$ ekstrak mengkudu (Morinda Citrifolia Liin) memenuhi syarat SNI menghambat pertumbuhan mikroba yaitu tidak melebihi da 1 x 104 koloni/mL. ${ }^{12}$ Ekstrak mengkudu (Morinda Citrifolia Liin) konsentrasi 12\% mempunyai daya hambat minimal terhadap Candida albican. ${ }^{9}$ Penelitian menyatakan bahwa lama perendaman 5 menit dengan mengkudu (Morinda Citrfolia Liin) 12\% dapat menurunkan jumlah koloni mikroorganisme 4 pada cetakan alginat. ${ }^{13}$ Berdasarkan uraian diatas perlu diperhatikan bahwa tujuan desinfeksi bahan cetak secara efektif untuk membunuh mikroorganisme patogen tanpa merusak dan mengurangi keakuratan dimensionalnya. Hal tersebut yang mendasari peneliti untuk melakukan penelitian pengaruh teknik desinfeksi perendaman dan penyemprotan cetakan alginat dengan ekstrak mengkudu (Morinda Citrifolia Liin) konsentrasi 12\%, 25\% dan 50\% dengan waktu 5 menit terhadap perubahan stabilitas dimensi alginat.

\section{Bahan dan Metode}

Jenis penelitian eksperimental laboratoris dengan rancangan penelitian post-test only control grup design, yang dilakukan dengan mengukur stabilitas cetakan alginat setelah dilakukan perendaman dan penyemprotan pada sampel dengan waktu penyimpanan yang telah ditentukan. 
Proses pembuatan ekstrak mengkudu (Morinda Citrifolia Liin) ${ }^{14:}$ Buah mengkudu (Morinda Citrifolia Liin) dikupas dan dipotong tipis-tipis kemudian dikeringkan dengan cara diangin-anginkan selama 3 hari dan tidak terkena sinar matahari langsung. Setelah buah mengkudu (Morinda Citrifolia Liin) kering, dihaluskan dengan blender sampai menjadi serat kasar. Serbuk yang halus kemudian dimasukkan didalam labu erlemeyer dan ditambahkan etanol 96\%. Selanjutnya larutan dimaserasi selama 24 jam pada suhu kamar, lalu difiltrasi menggunakan kertas penyaring. Kemudian residu penyaringan diangin-anginkan dan dilakukan maserasi ulang sampai 3 kali. Hasil saringan 1-3 dicampur dan dipekatkan dengan rotary vakum evaporator dengan suhu 45-500 C sampai didapatkan ekstrak kental 100\%. Pengenceran dilakukan dibuat dengan rumus V1.C1 = V2. C2. Sehingga didapatkan konsentrasi 12\%, 25\% dan 50\%.

Proses Pencetakan Alginat ${ }^{3}$ : Bubuk alginat ditakar sesuai dengan aturan pabrik yaitu bubuk $30 \mathrm{~g}$ : $60 \mathrm{ml}$ air dicampur ke dalam air lalu diaduk dengan gerakan angka delapan dan menekan ke arah tepi putaran intermiten (1800) selama 45 detik hingga homogen. Campuran adonan alginat ditempatkan pada sendok cetak yang sesuai dicetakkan pada model master dengan menggunakan sendok cetak berlubanglubang.Tunggu adonan alginat setting (3 menit) kemudian sendok cetak dilepas dari model master. Langkah 1-3 diulang untuk membuat sampel kelompok berikutnya.

Proses Perendaman ${ }^{4}$ : Membuat sampel cetakan alginat untuk kelompok kontrol positif, kemudian cetakan alginat dicuci dengan aquades selama 15 detik, selanjutnya cetakan alginat direndam selama 5 menit dengan larutan sodium hipoklorit $0,5 \% \pm 300 \mathrm{ml}$ kemudian diisi dental stone tipe III. Membuat sampel cetakan alginat untuk perlakuan I, kemudian cetakan alginat dicuci dengan aquades selama 15 detik, selanjutnya cetakan alginat direndam selama 5 menit dengan ekstrak mengkudu (Morinda Citrifolia Liin) $12 \% \pm 300 \mathrm{ml}$ kemudian diisi dental stone tipe III.Membuat sampel cetakan alginat untuk perlakuan II, kemudian cetakan alginat dicuci dengan aquades selama 15 detik, selanjutnya cetakan alginat direndam selama 5 menit dengan ekstrak mengkudu (Morinda Citrifolia Liin) 25\% \pm 300 ml kemudian diisi dental stone tipe III.Membuat sampel cetakan alginat untuk perlakuan III, kemudian cetakan alginat dicuci dengan aquades selama 15 detik, selanjutnya cetakan alginat direndam selama 5 menit dengan ekstrak mengkudu (Morinda Citrifolia Liin) 50\% $\pm 300 \mathrm{ml}$ kemudian diisi dental stone tipe III.Pencetakan alginat pada tiap kelompok tidak dilakukan secara bersamaan. Cetakan alginat yang telah setting langsung diberi perlakuan dan dicor kemudian baru dilanjutkan ke pencetakan yang kedua. Cetakan alginat harus dicor dengan gipsum maksimal 1 jam setelah pencetakan alginat. ${ }^{15}$

Proses Penyemprotan ${ }^{4}$ : Membuat sampel cetakan alginat untuk kelompok kontrol positif, kemudian cetakan alginat dicuci dengan aquades selama 15 detik, selanjutnya hasil cetakan disemprot dengan larutan sodium hipoklorit $0,5 \% \pm 3 \mathrm{ml}$ dengan jarak $\pm 5 \mathrm{ml}$ dan dibungkus dengan tisu yang telah dicelupkan dalam larutan desinfektan dan dimasukkan ke dalam kantung plastik selama 5 menit kemudian diisi dental stone tipe III. Membuat sampel cetakan alginat untuk perlakuan I, kemudian cetakan alginat dicuci dengan 
aquades selama 15 detik, selanjutnya cetakan alginat disemprot dengan ekstrak mengkudu (Morinda Citrifolia Liin) $12 \% \pm 3 \mathrm{ml}$ dengan jarak $\pm 5 \mathrm{ml}$ dan dibungkus dengan tisu yang telah diceplupkan dalam larutan desinfektan dan dimasukkan ke dalam kantung plastik selama 5 menit kemudian diisi dental stone tipe III. Membuat sampel cetakan alginat untuk perlakuan II, kemudian cetakan alginat dicuci dengan aquades selama 15 detik, selanjutnya cetakan alginat disemprot dengan ekstrak mengkudu (Morinda Citrifolia Liin) $25 \% \pm 3 \mathrm{ml}$ dengan jarak $\pm 5 \mathrm{ml}$ dan dibungkus dengan tisu yang telah dicepupkan dalam larutan desinfektan dan dimasukkan ke dalam kantung plastik selama 5 menit kemudian diisi dental stone tipe III. Membuat sampel cetakan alginat untuk perlakuan III, kemudian cetakan alginat dicuci dengan aquades selama 15 detik, selanjutnya cetakan alginat disemprot dengan ekstrak mengkudu (Morinda Citrifolia Liin) $50 \% \pm 3 \mathrm{ml}$ dengan jarak $\pm 5 \mathrm{ml}$ dan dibungkus dengan tisu yang telah dicepupkan dalam larutan desinfektan dan dimasukkan ke dalam kantung plastik selama 5 menit kemudian diisi dental stone tipe III. Pencetakan alginat pada tiap kelompok tidak dilakukan secara bersamaan. Cetakan alginat yang telah setting langsung diberi perlakuan dan dicor dengan dental stone tipe III. Kemudian baru dilanjutkan ke pencetakan yang kedua. ${ }^{15}$

Pembuatan Model Gips ${ }^{3,16}$ : Berikut ini cara pengisian gipsum ke dalam hasil cetak alginat: Menggunakan dental stone tipe III yang dimasukkan ke dalam rubber bowl dan ditambahkan air, dengan perbandingan yaitu bubuk 100gr: $20 \mathrm{ml}$ air diaduk selama 60 detik. Pengisian ke dalam bahan cetakan alginat dengan adonan gypsum dituangkan di atas vibrator agar seluruh bagian cetakan alginat rata tercetak dengan gipsum. Waktu yang diperlukan hingga gipsum mengeras 45- 60 menit.

Pengukuran Stabilitas Dimensi ${ }^{16}$ : Pengukuran dilakukan setelah gipsum mengalami final setting menjadi padat dan hasil berupa cetakan gipsum. Pengukuran dilakukan dengan menggunakan jangka sorong. Pengukuran dilakukan pada titik yang telah tercetak skrup. Pengukuran jarak vertikal atau AB diukur dari skrup anterior yang berada pada papilla insisiv ke arah posterior yang berada pada molar pertama kanan, AB memiliki ukuran awal 28,26 mm. Pengukuran jarak horizontal diukur dengan skrup posterior yang berada pada gigi molar pertama kanan ke skrup posterior yang berada pada gigi molar pertama kiri BC memiliki ukuran awal 42,05 mm. Persentase perubahan dimensi dapat dicari berdasarkan rumus: Model master-model gips dikali 100\% dibagi Model master

\section{Hasil Penelitian}

Besar sampel pada penelitian ini terdiri dari kelompok kontrol negatif, kontrol positif (sodium hipoklorit $0,5 \%$ ) dan kelompok perlakuan yang dibedakan berdasarkan perendaman dan penyemprotan dengan ekstrak mengkudu (Morinda Citrifolia Liin)12\%, 25\% dan 50\%. Hasil pengukuran dengan perendaman dan penyemprotan ditunjukkan pada tabel berikut. 
Tabel 1 Perubahan stabilitas dimensi pada cetakan alginat pada teknik perendaman jarak $\mathrm{AB}$ (anteroposterior) dan jarak BC (antar lengkung rahang)

\begin{tabular}{|c|c|c|c|}
\hline \multirow[b]{2}{*}{ Perlakuan } & \multirow[b]{2}{*}{$\mathrm{N}$} & \multicolumn{2}{|c|}{ Mean } \\
\hline & & $\mathrm{AB}(\mathrm{mm})$ & $\mathrm{BC}(\mathrm{mm})$ \\
\hline Kontrol Negatif & 3 & 28.26 & 42.05 \\
\hline Sodium Hipoklorit $0.5 \%$ & 3 & 28.29 & 42.09 \\
\hline Ekstrak Mengkudu (Morinda Citrifolia Liin) $50 \%$ & 3 & 28.28 & 42.09 \\
\hline Ekstrak Mengkudu (Morinda Citrifolia Liin) $25 \%$ & 3 & 28.37 & 42.19 \\
\hline Ekstrak Mengkudu (Morinda Citrifolia Liin) $12 \%$ & 3 & 28.40 & 42.20 \\
\hline
\end{tabular}

Tabel 2 Perubahan stabilitas dimensi pada cetakan alginat pada teknik penyemprotan jarak $\mathrm{AB}$ (anteroposterior) dan jarak BC (antar lengkung rahang)

\begin{tabular}{|c|c|c|c|}
\hline \multirow[b]{2}{*}{ Perlakuan } & \multirow[b]{2}{*}{$\mathrm{N}$} & \multicolumn{2}{|c|}{ Mean } \\
\hline & & $\mathrm{AB}(\mathrm{mm})$ & $\mathrm{BC}(\mathrm{mm})$ \\
\hline Kontrol Negatif & 3 & 28.26 & 42.05 \\
\hline Sodium Hipoklorit $0.5 \%$ & 3 & 28.28 & 42.07 \\
\hline Ekstrak Mengkudu (Morinda Citrifolia Liin) $50 \%$ & 3 & 28.27 & 42.06 \\
\hline Ekstrak Mengkudu (Morinda Citrifolia Liin) $25 \%$ & 3 & 28.33 & 42.10 \\
\hline Ekstrak Mengkudu (Morinda Citrifolia Liin) $12 \%$ & 3 & 28.37 & 42.12 \\
\hline
\end{tabular}

Tabel 3 Hasil Uji One Way Anova pada Ekstrak Mengkudu (Morinda Citrifolia Liin) 50\%

\begin{tabular}{lcccc}
\hline \multicolumn{1}{c}{ Kelompok } & N & Mean & Nilai F & Signifikansi \\
\hline Kontrol Negatif & 3 & 28,26 & 3,000 & 0,025 \\
Perendaman & 3 & 28.28 & \\
Penyemprotan & 3 & 28,27 & & \\
\hline
\end{tabular}

Berdasarkan hasil pengujian dengan One-way Anova diperoleh nilai rata-rata pada kontrol negatif 28,26 dan pada perlakuan dengan perendaman sebesar 28,28 dan pada perlakuan dengan penyemprotan sebesar 28,27. Nilai F hitung sebesar 3,000 dengan taraf signifikansi 0,025<0,05. Membuktikan bahwa terdapat perbandingan yang signifikan pada kontrol negatif, teknik desinfeksi penyemprotan dan perendaman pada perlakuan ekstrak mengkudu (Morinda Citrifolia Liin) 50\% dalam waktu 5 menit terhadap stabilitas dimensi pada cetakan alginat pada jarak $\mathrm{AB}$ (anteroposterior). 
SONDE (Sound of Dentistry) Vol 5 No 1

Tabel 4 Hasil Uji One Way Anova pada Ekstrak Mengkudu (Morinda Citrifolia Liin) 25\%

\begin{tabular}{lcccc}
\hline \multicolumn{1}{c}{ Kelompok } & N & Mean & Nilai F & Signifikansi \\
\hline Kontrol Negatif & 3 & 28,26 & 31,000 & 0.001 \\
Perendaman & 3 & 28,37 & & \\
Penyemprotan & 3 & 28,33 & & \\
\hline
\end{tabular}

Berdasarkan hasil pengujian dengan One-way Anova diperoleh nilai rata-rata pada kontrol negatif 28,26 dan pada perlakuan dengan perendaman sebesar 28,37 dan pada perlakuan dengan penyemprotan sebesar 28,33. Nilai F hitung sebesar 31,000 dengan taraf signifikansi 0,001 <0,05. Membuktikan bahwa terdapat perbandingan yang signifikan pada kontrol negatif, teknik desinfeksi penyemprotan dan perendaman pada perlakuan ekstrak mengkudu (Morinda Citrifolia Liin) 25\% dalam waktu 5 menit terhadap stabilitas dimensi pada cetakan alginat pada jarak $\mathrm{AB}$ (anteroposterior).

Tabel 5 Hasil Uji One Way Anova pada Ekstrak Mengkudu (Morinda Citrifolia Liin) 12\%

\begin{tabular}{lcccc}
\hline \multicolumn{1}{c}{ Kelompok } & N & Mean & Nilai F & Signifikansi \\
\hline Kontrol Negatif & 3 & 28,26 & 78,526 & 0.001 \\
Perendaman & 3 & 28,40 & \\
Penyemprotan & 3 & 28,37 & & \\
\hline
\end{tabular}

Berdasarkan hasil yang di dapat pada Tabel 5 pengujian dengan One-way Anova diperoleh nilai rata-rata pada kontrol negatif 28,26 dan pada perlakuan dengan perendaman sebesar 28,40 dan pada perlakuan dengan penyemprotan sebesar 28,37. Nilai F hitung sebesar 78,526 dengan taraf signifikansi 0,001 <0,05. Membuktikan bahwa terdapat perbandingan yang signifikan pada kontrol negatif, teknik desinfeksi penyemprotan dan perendaman pada perlakuan ekstrak mengkudu (Morinda Citrifolia Liin) 12\% dalam waktu 5 menit terhadap stabilitas dimensi pada cetakan alginat pada jarak AB (anteroposterior).

\section{Pembahasan}

Pada penelitian ini dilakukan teknik perendaman dan penyemprotan dengan sodium hipoklorit $0,5 \%$ dan ekstrak mengkudu (Morinda Citrifolia Liin) konsentrasi 12\%, 25\% dan 50\% pada Tabel 1 dan Tabel 2 didapatkan perolehan rata-rata dari setiap perlakuan, pada penelitian ini tedapat perbedaan dimensi pada setiap sampel disebabkan berbagai faktor diantaranya berkaitan dengan adanya compressed stress yang tidak diimbangi oleh strain saat melepas sendok cetak yang kurang cepat, maka stress yang diterima akan 
lebih besar dari strain-nya, hal tersebut dapat mengakibatkan permanen deformation. ${ }^{17}$ Perubahan stabilitas dimensi cetakan alginat juga dapat dipengaruhi oleh waktu, temperature ruangan, pengadukan alginat, rasio bubuk alginat dengan air dan rasio gips dengan air. Rasio pencampuran bahan cetak alginat penting untuk menjamin kehalusan dan homogennya campuran. Presentase perubahan dimensi yang terjadi pada perendaman sodium hipoklorit 0,5\%, ekstrak mengkudu (Morinda Citrifolia Liin) konsentrasi 12\%, 25\% dan $50 \%$ pada jarak AB (anteroposterior) adalah $0,10 \%, 0,49 \%, 0,38 \%, 0,07 \%$ dan presentase perubahan dimensi penyemprotan sodium hipoklorit 0,5\%, ekstrak mengkudu konsentrasi 12\%, 25\% dan 50\% jarak $\mathrm{AB}$ (anteroposterior) adalah $0,07 \%, 0,38 \%, 0,24 \%, 0,03 \%$ sedangkan presentase perubahan dimensi yang terjadi pada perendaman sodium hipoklorit 0,5\%, ekstrak mengkudu (Morinda Citrifolia Liin) konsentrasi $12 \%, 25 \%$ dan 50\% pada jarak BC (jarak antar lengkung rahang) adalah 0,09\%, 0,35\%, 0,33\%, 0,09\% dan presentase perubahan dimensi penyemprotan sodium hipoklorit 0,5\%, ekstrak mengkudu (Morinda Citrifolia Liin) konsentrasi 12\%, 25\% dan 50\% jarak BC (jarak antar lengkung rahang) adalah 0,04\%, $0,16 \%, 0,11 \%, 0,04 \%$. Spesifikasi ADA no. 19 , presentase perubahan dimensi pada ekstrak mengkudu konsentrasi $12 \%, 25 \%$ dan $50 \%$ baik dilihat dari teknik perendaman dan penyemprotan pada jarak $\mathrm{AB}$ (anteroposterior) dan BC (jarak antar lengkung rahang) masih dalam batas yang dapat ditolerir yaitu dibawah 0,5\%. ${ }^{18}$ Hasil penelitian uji Post Hoc (LSD) untuk melihat perbedaan masingmasing kelompok. Hasil uji Post Hoc (LSD) terdapat perbedaan yang tidak signifikan pada perlakuan perendaman dan penyemprotan kelompok sodium hipoklorit 0,5\% dengan ekstrak mengkudu (Morinda Citrifolia Liin) 50\%, pada teknik perendaman dan penyemprotan jarak BC (antar lengkung rahang) terjadi perbedaan yang tidak signifikan kontrol negatif dengan kontrol positif, kontrol positif dengan ekstrak mengkudu (Morinda Citrifolia Liin) $50 \%$ dan ekstrak mengkudu (Morinda Citrifolia Liin) 25\% dengan 12\%. Pengaruh desinfektan terhadap bahan cetak pada dasarnya bergantung dari jenis dan konsentrasi dari desinfektan. ${ }^{19}$ Ekstrak mengkudu (Morinda Citrifolia Liin) mengandung daya antibakteri seperti flavonoid, alizarin, acubin. Dalam flavonoid terkandung senyawa fenol yang merupakan suatu alkohol yang bersifat asam sehingga disebut juga asam karbolat yang mampu merusak membran sel, menginaktifkan enzim dan mendenaturasi protein pada bakteri sehingga dinding bakteri dapat mengalami kerusakan sehingga dapat mengakibatkan pertumbuhan sel akan terhambat dan sel mengalami kematian. ${ }^{13}$ Pada ekstrak mengkudu (Morinda Citrifolia Liin) 50\% terjadi perbedaan yang signifikan dengan ekstrak mengkudu (Morinda Citrifolia Liin) 12\% dan 25\% hal ini dikarenakan semakin sedikit konsentrasi larutan, maka larutan akan semakin encer, hal tersebut yang menyebabkan penyerapan yang lebih banyak pada cetakan alginat dan mengakibatkan perubahan dimensi yang lebih besar. Meskipun terdapat perbedaan yang signifikan pada uji One Way Anova pada penelitian ini baik pada teknik perendaman dan penyemprotan masih pada batas yang dapat di tolerir yaitu dibawah $0,5 \%$. 


\section{Simpulan}

Adanya perubahan stabilitas dimensi cetakan alginat pada teknik perendaman jarak $\mathrm{AB}$ dan $\mathrm{BC}$, pada ekstrak mengkudu (Morinda Citrifolia Liin) konsentrasi 12\% dan $25 \%$ mengalami peningkatan yang lebih tinggi dibandingkan pada konsentrasi 50\% tetapi masih pada batas toleransi klinik yaitu dibawah 0,5\%. Pada teknik penyemprotan ekstrak buah mengkudu (Morinda Citrifolia Liin) mempunyai presentase perubahan yang lebih kecil dibandingan teknik perendaman. Jadi lebih baik menggunakan konsentrasi 50\% dengan teknik penyemprotan ekstrak buah mengkudu (Morinda Citrifolia Liin).

\section{Daftar Pustaka}

1. Zulkarnain M, dan Devina S. Pengaruh penyemprotan daun sirih dan sodium hipoklorit pada cetakan elastomer terhadap perubahan dimensi. Jurnal Material Kedokteran Gigi. 2016;5(2):34-44.

2. Sousa JC, Tabaio AM, Silva A, Tania, Vsconcelos M. The effect of water and sodium hypoclorite disinfection on alginate impresionsi. Research Faculty of Dental Medicine of Porto. 2013;53(1):8-12.

3. Anusavice KJ, Phillips. Science of Dental Materials 12th edition. 2012:239- 340.

4. Sari DF, Parnaadji RR, Sumono A. Pengaruh teknik desinfeksi dengan berbagai macam larutan desinfektan pada hasil cetakan alginat terhadap stabilitas dimensional. Jurnal Pustaka Kesehatan. 2013;1(1):29-34.

5. Ongo TA, Rachmadi P, Arya IW. Stabilitas dimensi hasil cetakan bahan cetak elastomer setelah disemprot menggunakan sodium hipoklorit. Dentino Jurnal Kedokteran Gigi. 2014;2(1):83-88.

6. Parimata VN, Rachmadi P, Arya IW. Stabilitas dimensi hasil cetakan alginat setelah dilakukan penyemprotan infusa daun sirih merah (Piper Crocatum Ruiz \& Pav) 50\% sebagai desinfektan. Dentino Jurnal Kedokteran Gigi. 2014;2(1):74-78.

7. Lamiah D, Parnaadji RR, Sumono A. Pengaruh desinfeksi dengan teknik spray rebusan daun sirih hijau (Piper Betle L.) $35 \%$ dan sodium hipoklorit (Naocl) 0,5\% pada model hasil cetakan alginat terhadap stabilitas dimensi. Jurnal Pustaka Kesehatan. 2016;3(3):530-535.

8. Sastrodihardjo S. Desinfeksi hasil cetakan. Jurnal Material Kedokteran Gigi. 2016;5(2):45-51.

9. Ilyas M. Daya hambat ekstrak buah mengkudu terhadap pertumbuhan candida albicans. Dentofasial. 2008;7(1):7-12

10. Djuramang RR, Retnowati Y, Bialang N. Pengaruh ekstrak buah mengkudu (Morinda Citrifolia) terhadap pertumbuhan staphylococcus aureus. Universitas Muhammadiyah Luwuk. 2017;1(2):62-67

11. Dharmawati IGA, Swastini IGGA, Widhiasti NM. Efek berkumur ekstrak mengkudu dapat menghambat pertumbuhan Streptococcus Sp sebagai penyebab terjadinya plak gigi. Dental Journal. 2014:18(2):111-115. 
12. Sakti M. Pengaruh lama perendaman cetakan alginate dalam perasan mengkudu (Morinda Cifriafolia Linn) terhadap pertumbuhan mikrooganisme rongga mulut. Skripsi. Universitas Airlangga Surabaya. 2006.

13. Nonci FY, Rusli, Jumanti. Uji efektivitas antibakteri sari buah mengkudu (Morinda Citrifolia L.) asal Makasar pada daging sapi. Jurnal Farmasi. 2015;3(1):17-21.

14. Malinggas F, Pangemanan DHC, Mariat. Uji daya hambat ekstrak buah mengkudu (M. Citrifolia, L) terhadap pertumbuhan Streptococcus Mutans secara in vitro. Pharmacon. 2015;4(4):22-26.

15. Bird L, Robinson S. Modern dental assisting. Edisi 10. Canada Elsevier Saunders. 2012:283-316.

16. Rahmayani L, Sofya PA, Ramadhani. The diffrerence of dimensional change in alginate impression after immersion in disinfectant solution sodium hypochlorite 0,5\% and dettol 5\%. Proceeding Medan Internasional Scientific Dental Meeting. 2017:64-65.

17. Mc Cabe JF, Walls WG. Applied dental material. 1st. Oxord, 2008:140.

18. Walker MP, Burckhard J, Mitts DA, Williams KB. Dimensional change over time of extended-storage alginate impression material. Angel orthod. 2010;80(6):1110-15.

19. Amalan A, Ginjupalli K, Upadhya PN. Evaluation of properties of irreversible hydrocolloid impresion material mixed with disinfectan liquid. Dental Research Journal. 2019;10(1):65-67. 